\title{
Subsiding Sundaland
}

\author{
A.-C. Sarr ${ }^{1,2}$, L. Husson 1 , P. Sepulchre ${ }^{2}$, A-M. Pastier ${ }^{1,3,4}$, K. Pedoja ${ }^{5}$, M. Elliot ${ }^{4}$, C. Arias-Ruiz ${ }^{4}$, T. Solihuddin ${ }^{6}$, S. Aribowo ${ }^{7}$, \\ and Susilohadi ${ }^{8}$ \\ ${ }^{1}$ ISTerre, Université Grenoble Alpes, CNRS, 38058 Grenoble, France \\ 'Laboratoire des Sciences du Climat et de l'Environnement, LSCE/IPSL, CEA-CNRS-UVSQ, Université Paris Saclay, France \\ ${ }^{3}$ Géosciences Rennes, Université Rennes-1, 35042 Rennes Cedex, France \\ ${ }^{4}$ Laboratoire de Planétologie et Géodynamique, Université Nantes, CNRS, 44300 Nantes, France \\ ${ }^{5}$ Laboratoire de Morphodynamique Continentale et Côtière Caen, Université Caen, CNRS, 14000 Caen, France \\ ${ }^{6}$ Marine Research Center, Ministry of Marine Affairs and Fisheries, Jakarta, Indonesia \\ ${ }^{7}$ Indonesian Institute of Sciences (LIPI), Research center for Geotechnology, Bandung, Indonesia \\ ${ }^{8}$ Marine Geological Institute, Marine Geological Research and Development Centre, Bandung, Indonesia
}

\section{ABSTRACT}

Sundaland is the currently partially drowned continental landmass that encompasses Borneo, Sumatra, Java, and the Malay Peninsula. It has episodically been reclaimed by the sea during successive Quaternary glaciations, and is commonly thought to be vertically stable. Combining geomorphological observations with numerical simulations of coral reef growth and shallow seismic stratigraphy, we show that the Sunda shelf is subsiding, and that the intermittent regime of transgressions only prevailed over the past 400,000 yr. Prior to that time, Sundaland was permanently exposed. We relate these drowning events to transient dynamic topography in the Indo-Australian subduction zone. Because the Sunda shelf is very shallow, these new data provide important insights into Pleistocene paleogeography, with implications on the interactions between the solid Earth and climate, oceanography, and dispersal of species, including hominids.

\section{LARGE-SCALE DEFORMATION PATTERN IN SOUTHEAST ASIA}

Cenozoic Sundaland (the area that encompasses Borneo, Sumatra, Java, the Malay Peninsula, and the Java Sea) paleogeographies are available up to the Early Pliocene (e.g., Hall, 2009) but its more recent paleogeography remains largely unknown. The core of Sundaland is nearly tectonically quiescent (Fig. 1A), and flooding of its shallow areas $(<100 \mathrm{~m}$ depth) is regarded as only contingent on eustatic sea-level changes (Voris, 2001); the Sunda shelf being fully exposed during Quaternary glacial periods, and partly drowned during interglacials, as it is today. However, the shelf's location above the quickly evolving Indo-Australian subduction zone, where mantle convection efficiently modifies the physiography (Zahirovic et al., 2016), challenges the default assumption of stability for the shelf. That assumption, which has implications for the Neogene biogeography of Southeast Asia (e.g., Richardson et al., 2013), has not yet been properly tested.

Wallacea (Eastern Indonesia, mostly) actively deforms in response to the collision with Australia (e.g., Pownall et al., 2016). Flights of uplifted marine terraces are widespread and attest to an overall Pleistocene uplift of Wallacea (e.g., Pedoja et al., 2018; Table DR1 in the GSA Data Repository ${ }^{1}$ ). Conversely, wide alluvial plains stretch over most
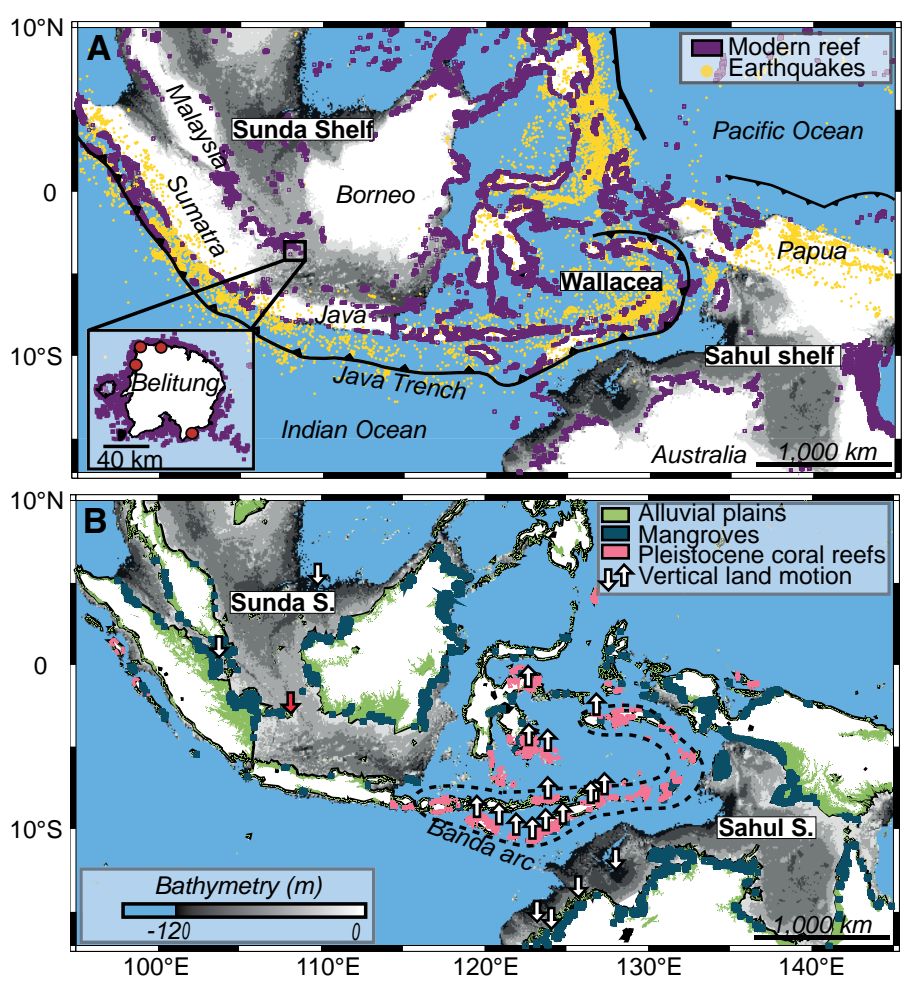

Figure 1. Quaternary coastal morphotectonics in Southeast Asia. A: Earthquakes (M > 4 ; U.S. Geological Survey catalog, 1960-2010; https:// earthquake.usgs.gov/earthquakes/search/) outline the low-seismicactivity area within Sundaland. Inset: Location of dated mid-Holocene reef on Belitung island (red circles). Modern coral reefs are ubiquitous (A) whereas Pleistocene reefs (B) are only found in Wallacea. B: Alluvial plains and mangroves prevail in the Sunda and Sahul shelves, and Pleistocene reefs in Wallacea. Vertical land motion (Table DR1 [see footnote 1]) reveal uplift in Wallacea and subsidence in Sunda and Sahul (white arrows; current study in red). Sundaland encompasses the Sunda shelf, Malay Peninsula, Borneo, Java, and Sumatra. Sahul is the shallow north Australian platform, while the deeper Wallacea lies between Sahul and Sundaland.

'GSA Data Repository item 2019048, Tables DR1 and DR2 and Figures DR1-DR4, including raw seismic profile and information on the model used for this study, is available online at http://www.geosociety.org/datarepository/2019/, or on request from editing@ geosociety.org. 
coastal regions of Sahul and Sunda, and extend hundreds of kilometers inland (Fig. 1B). Onshore marine sediments, and reefs older than Holocene age, are never exposed even though reefs bloomed in the region during the late Cenozoic (Wilson and Rosen, 2008) and currently thrive in Southeast Asia, including Sunda and Sahul (Fig. 1A). Such contrasting morphologies between Wallacea and surrounding shelves are the consequence of different uplift and subsidence histories (Evans et al., 1936). Late Quaternary subsidence rates for the Sunda shelf are only reported on the northern margin (0.13-0.27 $\mathrm{mm} \mathrm{yr}^{-1}$,Wong et al., 2003; $0.25 \mathrm{~mm} \mathrm{yr}^{-1}$, Hanebuth et al., 2011) or in the Singapore strait (0.06-0.10 $\mathrm{mm} \mathrm{yr}^{-1}$, Bird et al., 2006) but are absent from the core of the shelf (Fig. 1B). Sahul subsides at $0.12-0.45 \mathrm{~mm} \mathrm{yr}^{-1}$ (Table DR1) and, based on its morphological similarity with Sunda (Fig. 1B), we hypothesize that rather than being vertically stable, the Sunda shelf may be experiencing similar long-wavelength subsidence. While the shelf is currently drowned at $30 \mathrm{~m}$ below sea level (bsl), the absence of marine sediments onshore and the thin layer of alluvia that overlays laterites and substratum (BenAvraham and Emery, 1973) attest to continental Cenozoic erosion and recent inundation (Hall and Morley, 2004).

Here we use morphological indicators (coastal landforms such as modern and fossil reefs, mangroves, and alluvial plains; Fig. 1B) and shallow stratigraphy to capture the pattern of Pleistocene vertical land motion in Southeast Asia. We focus on the Tin Belt islands, in the inner Sunda shelf, and combine numerical modeling of reef growth with ${ }^{14} \mathrm{C}$ dating of mid-Holocene reefs to constrain subsidence rates in this region where almost no data exist, ultimately demonstrating the uniformity of subsidence in the Sunda shelf.

\section{SUNDA SHELF SUBSIDENCE}

In order to quantify subsidence rates, we use sequences of coral reefs that fingerprint sea-level oscillations, and ubiquitously stack in flights of marine terraces in the intertropical zone (Pedoja et al., 2014). Those reef sequences are indirect sensors of a variety of parameters, including uplift or subsidence rates that numerical models can invert for (Toomey et al., 2013). We develop an original probabilistic approach, based on a numerical model that reproduces the inferred architecture of coral reef sequences calibrated by field measurements, to probe Quaternary subsidence rates for the Sunda shelf (Husson et al., 2018; see the Data Repository). Model predictions depend on parameterized reef growth, wave erosion, sedimentation, and relative sea level that follow glacial cycles and vertical land motion. This method brackets the parameter space - including subsidence rates-that accurately reproduces observations.

Our case study is Belitung Island (Fig. 1A, inset), which stands in the shallowest part of the Sunda shelf. This area has negligible seismic activity and is distant from the orogenic or sedimentary loads that develop on the edge of the Sunda shelf (e.g., Pubellier and Morley, 2014). Narrow (up to $\sim 1500 \mathrm{~m}$ ), flourishing fringing reefs surround Belitung and are immune from terrigenous fluxes that could hamper their development. They are developing seaward of prograding alluvial plains and mangroves (Fig. 2A; Fig. DR2), over shallow-dipping basement ( $<2.5 \%$ slope). Only the midHolocene sea-level highstand left a marine fingerprint on the island: scores of mid-Holocene micro-atolls lie immediately below the modern shore (Meltzner et al., 2017). We obtained ${ }^{14} \mathrm{C}$ ages from a fossil reef that is recurrently found at $\sim 2 \mathrm{~m}$ bsl, up to $3 \mathrm{~km}$ onshore (as collected from tin mine pits) at $6.5 \mathrm{kyr}$ B.P., and on a micro-atoll (6.7 kyr B.P.) (see the Data Repository; Fig. 1A, inset). Offshore, sonar measurements (see the Data Repository) and underwater observations reveal the existence of a single reef body down to $10-15 \mathrm{~m}$ bsl (Fig. 2A). An additional reef body from the Last Interglacial Maximum (ca. $125 \mathrm{kyr}$ B.P.) could potentially be buried under several meters of sediments at $\sim 30 \mathrm{~m}$ bsl, as interpreted from a seismic profile offshore Karimata island (Aleva et al., 1973).

Our model (Fig. 2B) reveals that such a condensed reef sequence can only develop within a narrow range of subsidence rates and slopes.
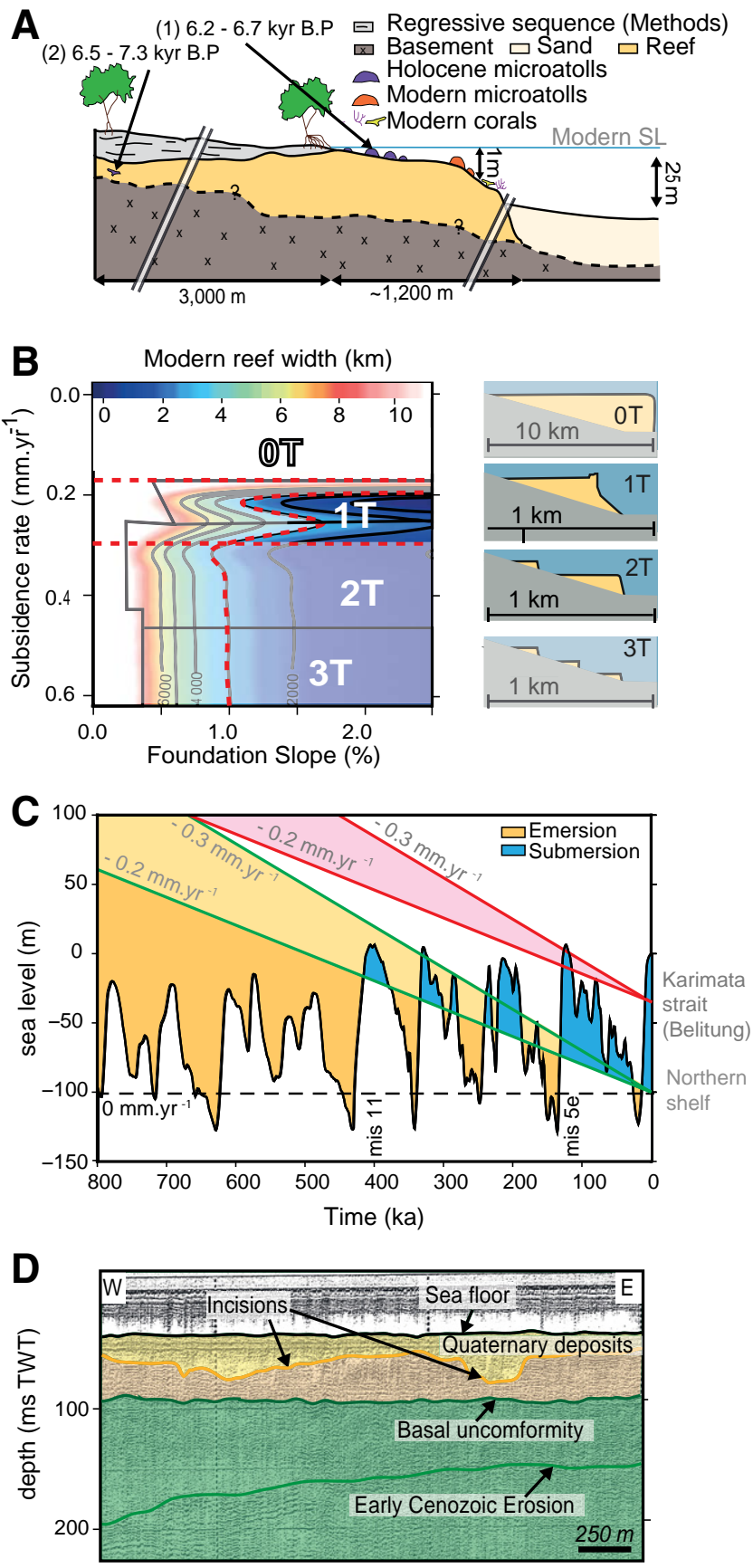

Figure 2. Reef morphologies and subsidence rates in the Sunda shelf, Indonesia. A: Belitung island has a $1200-\mathrm{m}-$ wide modern reef that progrades seaward above the granitic basement, as inferred from radiocarbon-dated mid-Holocene micro-atolls (1) from the intertidal zone, and mid-Holocene coral reefs (2) up to $3 \mathrm{~km}$ onshore. SL-sea level. B: Modeled architectures of reef sequences (right) with subsidence rates of $0.2-0.45 \mathrm{~mm} \mathrm{yr}^{-1}$ (left) successfully reproduce observed reef morphologies (1-2-km-wide modern reef, 1-2 reef bodies). Dated Holocene samples bracket subsidence rates between $0.2 \mathrm{~mm} \mathrm{yr}^{-1}$ and $0.3 \mathrm{~mm} \mathrm{yr}^{-1}$ (red lines) T-number of reef bodies. C: In the absence of subsidence (dashed horizontal line, present paradigm), the shelf is only exposed during glacials, when sea level was lower than the deepest parts of the Sunda shelf ( $100 \mathrm{~m}$ below sea level [bsl]). Instead, subsidence implies that the entire shelf was permanently exposed prior to $400 \mathrm{ka}$ (where the green domain and black sea-level curve intersect), and is reliant on sea-level oscillations afterward. The $~ 35-$ m-deep Karimata Strait, near Belitung Island, was first flooded during Marine Isotope Stage (MIS) 5e (red domain). D: Shallow seismic profile across the Sunda shelf showing incised layers of sediments over the Cretaceous-Eocene basement (raw seismic data are provided in Fig. DR1C [see footnote 1]). TWT-two-way traveltime. 
Reefs narrower than $10 \mathrm{~km}$ only appear when subsidence rates exceed $0.2 \mathrm{~mm} \mathrm{yr}^{-1}$, and fossil reefs stack in sequences at rates greater than $0.45 \mathrm{~mm} \mathrm{yr}^{-1}$, whereas extremely wide, single-body reef flats develop at subsidence rates lower than $0.2 \mathrm{~mm} \mathrm{yr}^{-1}$ (Fig. 2B). The width of the reef decreases with increasing slope, while the potential growth rate neither sets the number of terraces nor the width of the modern reef (Fig. DR3). The observed reef architecture of Belitung, which includes one or two terraces with a 1500 -m-wide flat modern reef, is reproduced by our model for mean subsidence rates ranging from 0.2 to $0.45 \mathrm{~mm} \mathrm{yr}^{-1}$, with a slope of $1.5 \%-2.5 \%$ (Fig. 2B).

Additional constraints come from the mid-Holocene coral (Porites gn., ${ }^{14} \mathrm{C}$ dated; Fig. $2 \mathrm{~A}$ ) buried $3 \mathrm{~km}$ onshore at $\sim 2 \mathrm{~m}$ bsl., that attest to seaward reef progradation, and from the mid-Holocene micro-atolls that stud the current shoreline (Meltzner et al., 2017): (1) progradation suggests that subsidence is slower than late-Holocene sea-level fall, and (2) sclerochronology on micro-atolls limits sea-level fall since the midHolocene highstand to $\sim 1.5 \pm 0.3 \mathrm{~m}$ (Meltzner et al., 2017). Taken together, these constraints further limit subsidence rates to a maximum of $0.3 \mathrm{~mm}$ $\mathrm{yr}^{-1}$ (Fig. 2C). The other small islands of the central Sunda shelf (Karimata, Tudjuh, Bangka, and Natuna; Fig. DR2) all display reef morphologies and Quaternary sediment sequences similar to Belitung Island under identical environmental conditions.

Our echosounder survey in the center of the Sunda shelf shows few thin layers of sediments that are (1) discordant on the basement, (2) undeformed and/or uneroded, and (3) only incised by an intermittent drainage of the shelf (Fig. 2D; Fig. DR1). North of Belitung, a single incised layer is found underneath a second layer, while up to five layers are found at greater depths (e.g., Darmadi et al., 2007; Alqahtani et al., 2015). These successive layers likely only mark Marine Isotope Stage 5 (MIS5) and Holocene transgressions in the center of the shelf, and MIS11 to Holocene transgressions in deeper regions (ca. $400 \mathrm{ka}$ ), which is consistent with subsidence rates of $0.2-0.3 \mathrm{~mm} \mathrm{yr}^{-1}$ throughout (Fig. 2C).

\section{DISCUSSION}

The similarity of reef morphologies of the Tin Belt Islands (Fig. DR2), together with insights from seismic stratigraphy and comparable Pleistocene subsidence rates from the north of the Sunda shelf (Wong et al., 2003; Hanebuth et al., 2011) and Singapore strait (Bird et al., 2006), allow us to deem subsidence rates from Belitung as representative of Pleistocene rates of the entire Sunda shelf; at $0.2-0.3 \mathrm{~mm} \mathrm{yr}^{-1}$ (Fig. 2C). It follows that land connections permanently operated in Sundaland during the early Pleistocene, and started to vanish periodically during sea-level highstands only after MIS11 (ca. $400 \mathrm{ka}$, Late Pleistocene) in the deepest parts of the shelf; the shallow Karimata strait being only inundated during MIS5e

Active tectonics in the central part of the Sunda shelf is currently almost null (Fig. 1A), making transient dynamic topography, triggered by the underlying mantle flow, the likely cause of subsidence. Slow paleogeographic changes in Southeast Asia have been attributed to changing dynamic topography (e.g., Zahirovic et al. 2016), and also for Sahul, where subsidence mirrors the northward dynamic subsidence of the Australian continent (Czarnota et al., 2012). Here we suggest that current short-lived geodynamic events profoundly alter the physiography of Sundaland, at a much faster rate than long-term subsidence and paleogeographic changes. The Indo-Australian plate has steadily subducted underneath Sundaland and Wallacea, from Sumatra to the Banda arc (Fig. 1A), but disturbances come from heterogeneities entering the Sunda trench. Examples are many during the Miocene-Pliocene, near Sumba (Rigg and Hall, 2011), or Eastern Java (Hall and Spakman, 2015), and more importantly near Timor, where the Australian continental margin (Scott Plateau) entered the trench less than 5 m.y. ago, while oceanic subduction has continuously operated to the west (Hall, 2011; Fig. 3A). The entry of continental blocks in subduction zones disrupts mantle flow and, in turn, the dynamic deflection of the overriding plates (e.g., Guillaume et al., 2013): it first causes a wholesale
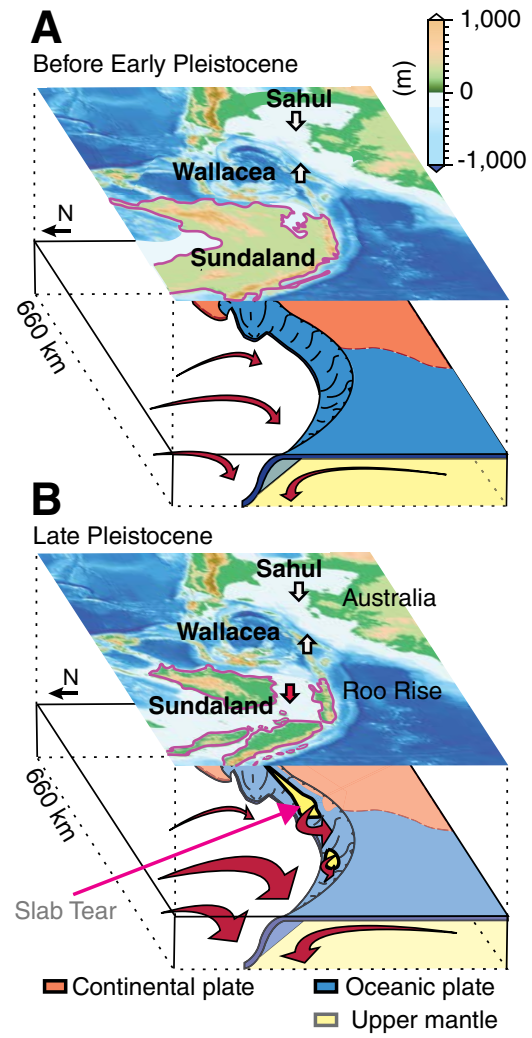

Figure 3. Mantle flow (red arrows), dynamic surface deformation, and associated interglacial paleogeography changes of Sundaland, Indonesia. A: Impingement of the Roo Rise and Australian continent: idle subduction and emersion. B: Following slab tearing, vigorous subduction resumes; subsidence and transgression follow.

uplift of the entire overriding plate, as the overall vigor of the subduction decreases. Then, oceanic slab-pull stretches and ultimately ruptures the slab at the ocean-continent boundary (the torn and disrupted slabs beneath Java or Banda are plausible illustrations, sketched in Figure 3B, although their nature is still debated; Ely and Sandiford, 2010; Widiyantoro et al., 2011; Hall and Spakman, 2015). As the oceanic segment separates from the continental unit, rapid subduction resumes, slab suction underneath the lithosphere simultaneously increases, and dynamic subsidence is expected (e.g., Guillaume et al., 2013). We therefore suggest that Late Quaternary flooding of the Sunda shelf can only result from transient mantle dynamics, and that it is such a geodynamic epiphenomenon that reshaped the paleogeography of Sundaland. Overall, we argue that dynamic topography favored land connections between Eurasia and Indonesian islands until 400 ka and interrupted them afterward. In the absence of dynamic subsidence, Sundaland would have remained mostly continental until today, regardless of sea-level oscillations. Paleogeographic changes in Sundaland impact the oceanic and atmospheric segments of the regional climate system. Exposing the shelf implies shutting the Karimata strait outflow, which currently feeds the Indonesian Throughflow and in turn sets the surface temperature and salinity of the eastern Indian Ocean (Sprintall et al., 2014). With contrasting results, climate modeling experiments have also suggested that shelf exposure alters atmospheric circulation over the Maritime Continent, the Walker circulation, and El Niño-Southern Oscillation (DiNezio et al., 2016; Tozuka et al., 2015).

A subsiding Sundaland also impacts the biosphere: understanding biogeographic patterns (including Homo erectus; see Wurster and Bird, 2016) between Eurasia, Sundaland, and Wallacea requires constraining the paleogeography and paleoclimate during the late Miocene and Quaternary, since dispersal and diversification occur at both time scales (e.g., Richardson et al., 2013). Hypotheses regarding the latest dispersal routes are grounded on the premise that Sundaland has remained vertically stable during the Quaternary, with glacial low sea levels periodically exposing the Sunda shelf land bridge between mainland Asia and the Indonesian islands (de Bruyn et al., 2014). Our results, by suggesting that the Sunda 
shelf was exposed regardless of sea-level change before $400 \mathrm{ka}$, imply that permanent land connections existed until MIS11, and these results might lead to a reevaluation of biogeographic and dispersal patterns of species in Sundaland during the Quaternary.

Ultimately, subsiding Sundaland remarkably illustrates the links between the solid Earth and the soft Earth (hydrosphere-, atmosphere, and biosphere).

\section{ACKNOWLEDGMENTS}

This work has been supported by CNRS (Centre National de la Recherche Scientifique) programs Syster, PICS, and Artemis. We thank D. Paillard for discussions, and B. Duffy, R. Morley, J. Pownall, and M. Pubellier for their reviews. Thanks to our friends Meggi Rhomadona and Stéphane (GoBelitung) for their phenomenal assistance in the field.

\section{REFERENCES CITED}

Aleva, G.J.J., Bon, E.H., Nossin, J.J., and Sluiter, W.J., 1973, A contribution to the geology of part of the Indonesian tinbelt: The sea areas between Singkep and Bangka islands and around the Karimata islands: Geological Society of Malaysia, v. 6, p. 257-271.

Alqahtani, F.A., Johnson, H.D., Jackson, C.A.-L., and Som, M.R.B., 2015, Nature, origin and evolution of a Late Pleistocene incised valley-fill, Sunda Shelf, Southeast Asia: Sedimentology, v. 62, p. 1198-1232, https://doi.org /10.1111/sed.12185.

Ben-Avraham, Z., and Emery, K.O., 1973, Structural framework of Sunda Shelf: American Association of Petroleum Geologists Bulletin, v. 57, p. 2323-2366.

Bird, M.I., Pang, W.C., and Lambeck, K., 2006, The age and origin of the straits of Singapore: Palaeogeography, Palaeoclimatology, Palaeoecology, v. 241, p. 531-538, https://doi.org/10.1016/j.palaeo.2006.05.003.

Czarnota, K., Hoggard, M.J., White, N., and Winterbourne, J., 2012, Spatial and temporal pattern of Cenozoic dynamic topography around Australia: Geochemistry Geophysics Geosystems, v. 14, p. 634-658, https://doi.org/10.1029 /2012GC004392.

Darmadi, Y., Willis, B.J., and Dorobek, S.L., 2007, Three-Dimensional seismic architecture of fluvial sequences on the low-gradient Sunda shelf, offshore Indonesia: Journal of Sedimentary Research, v. 77, p. 225-238, https://doi org/10.2110/jsr.2007.024.

de Bruyn, M., et al., 2014, Borneo and Indochina are major evolutionary hotspots for Southeast Asian biodiversity: Systematic Biology, v. 63, p. 879-901, https://doi.org/10.1093/sysbio/syu047.

Di Nezio, P., Timmermann, A., Tierney, J.E., Jin, F., Otto-Bliesner, B., Rosenbloom, N., Mapes, B., Ivanovic, R.F., and Montenegro, A., 2016, The climate response of the Indo-Pacific warm pool to glacial sea level: Paleoceanography, v. 31, p. 866-894, https://doi.org/10.1002/2015PA002890.

Ely, K.S., and Sandiford, M., 2010, Seismic response to slab rupture and variation in lithospheric structure beneath the Savu sea, Indonesia: Tectonophysics, v. 483, p. 112-124, https://doi.org/10.1016/j.tecto.2009.08.027.

Evans, P., et al., 1936, The geological evidence for recent submergence of the Assam-Malay-Australia region: Proceedings of the National Academy of Sciences of India, v. 2, p. 145-153.

Guillaume, B., Husson, L., Funiciello, F., and Faccenna, C., 2013, The dynamics of laterally variable subductions: Laboratory models applied to the Hellenides: Solid Earth, v. 4, p. 179-200, https://doi.org/10.5194/se-4-179-2013.

Hall, R., 2009, Southeast Asia's changing palaeogeography: Blumea, v. 54, p. 148161, https://doi.org/10.3767/000651909X475941.

Hall, R, 2011, Australia-SE Asia collision: Plate tectonics and crustal flow, in Hall, R., et al., eds., The SE Asian Gateway: History and Tectonics of the AustraliaAsia Collision: Geological Society of London Special Publications, v. 355, p. 75-109, https://doi.org/10.1144/SP355.5.

Hall, R., and Morley, C.K., 2004, Sundaland Basins: Continent-ocean interactions within East Asian marginal seas, in Clift, P., et al., Sundaland Basins: American Geophysical Union Geophysical Monograph Series, v. 149, p. 55-85, https:// doi.org/10.1029/149GM04.

Hall, R., and Spakman, W., 2015, Mantle structure and tectonic history of SE Asia: Tectonophysics, v. 658, p. 14-45, https://doi.org/10.1016/j.tecto.2015.07.003.

Hanebuth, T.J.J., Voris, H.K., Yokoyama, Y., Saito, Y., and Okuno, J., 2011, Formation and fate of sedimentary depocentres on Southeast Asia's Sunda Shelf over the past sea-level cycle and biogeographic implications: Earth-Science Reviews, v. 104, p. 92-110, https://doi.org/10.1016/j.earscirev.2010.09.006. Husson, L., Pastier, A.-M., Pedoja, K., Elliot, M., Paillard, D., Authemayou, C., Sarr, A.-C., Schmitt, A., and Cahyarini, S.Y., 2018, Reef carbonate productivity during Quaternary sea level oscillations: Geochemistry Geophysics Geosystems, v. 19, p. 1148-1164, https://doi.org/10.1002/2017GC007335.

Meltzner, A.J., et al., 2017, Half-metre sea-level fluctuations on centennial timescales from mid- Holocene corals of Southeast Asia: Nature Communications, v. 8 , p. 14387 , https://doi.org/10.1038/ncomms14387.

Pedoja, K., et al., 2014, Coastal staircase sequences reflexting sea-level oscillations and tectonic uplift during the Quaternary and Neogene: Earth-Science Reviews, v. 132, p. 13-38, https://doi.org/10.1016/j.earscirev.2014.01.007.

Pedoja, K., et al., 2018, On the long-lasting sequences of coral reef terraces from SE Sulawesi (Indonesia): Distribution, formation, and global significance: Quaternary Science Reviews, v. 188, p. 37-57, https://doi.org/10.1016/j .quascirev.2018.03.033.

Pownall, J.M., Hall, R., and Lister, G.S., 2016, Rolling open Earth's deepest forearc basin: Geology, v. 44, p. 947-950, https://doi.org/10.1130/G38051.1.

Pubellier, M., and Morley, C.K., 2014, The basins of Sundaland (SE Asia): Evolution and boundary conditions: Marine and Petroleum Geology, v. 58, p. 555578, https://doi.org/10.1016/j.marpetgeo.2013.11.019.

Richardson, J.E., Bakar, A.M., Tosh, J., Armstrong, K., Smedmark, J., Anderberg, A.A., Slik, E., and Wilkie, P., 2013, The influence of tectonics, sealevel changes and dispersal on migration and diversification of Isonandreae (Sapotaceae): Botanical Journal of the Linnean Society of London, v. 174, p. 130-140, https://doi.org/10.1111/boj.12108.

Rigg, J.W.D., and Hall, R., 2011, Structural and stratigraphic evolution of the Savu Basin, Indonesia, in Hall, R., et al., eds., The SE Asian Gateway: History and Tectonics of the Australia-Asia Collision: Geological Society of London Special Publications, v. 355, p. 225-240, https://doi.org/10.1144/SP355.11.

Sprintall, J., Gordon, A.L., Koch-Larrouy, A., Lee, T., Potemra, J.T., Pujiana, K. and Wijffels, S.E., 2014, The Indonesian seas and their role in the coupled ocean-climate system: Nature Geoscience, v. 7, p. 487-492, https://doi.org /10.1038/ngeo2188.

Toomey, M., Ashton, A.D., and Perron, T., 2013, Profiles of ocean island coral reefs controlled by sea-level history and carbonate accumulation rates: Geology, v. 41, p. 731-734, https://doi.org/10.1130/G34109.1.

Tozuka, T., Qu, T., and Yamagata, T., 2015, Impacts of South China Sea throughflow on the mean state of El Niño/Southern Oscillation as revealed by coupled GCM: Journal of Oceanography, v. 71, p. 105-114, https://doi.org/10.1007 /s10872-014-0265-1.

Voris, H.K., 2001, Maps of pleistocene sea levels in southeast asia: Shorelines, river systems and time durations: Journal of Biogeography, v. 27, p. 1153-1167, https://doi.org/10.1046/j.1365-2699.2000.00489.x

Widiyantoro, S., Pesicek, J.D., and Thurber, C.H., 2011, Subducting slab structure below the eastern Sunda arc inferred from non-linear seismic tomographic imaging, in Hall, R., et al., eds., The SE Asian Gateway: History and Tectonics of the Australia-Asia Collision: Geological Society of London Special Publications, v. 355, p. 139-155, https://doi.org/10.1144/SP355.7.

Wilson, M.E.J., and Rosen, B.R., 2008, Implications of paucity of corals in the Paleogene of SE Asia: Plate tectonics or Centre of Origin? in Hall, R., and Holloway, J.D., eds., Biogeography and Geological Evolution of SE Asia: Leiden, Netherlands, Backhuys Publishers, p. 165-195.

Wong, H.K., Lüdmann, T., Haft, C., and Paulsen, A.-M., 2003, Quaternary sedimentation in the Molengraaff paleo-delta, northern Sunda-shelf (Southern South China Sea), in Hasan Sidi, F., et al., Tropical Deltas of Southeast AsiaSedimentology, Stratigraphy, and Petroleum Geology: The Society for Sedimentary Geology Special Publications, v. 76, p. 201-216, https://doi.org/10 $.2110 /$ pec.03.76.0201.

Wurster, C.M., and Bird, M.I., 2016, Barriers and bridges: Early human dispersals in equatorial SE Asia, in Harff, J., et al., eds., Geology and Archeology: Submerged Landscapes of the Continental Shelf: Geological Society of London Special Publications, v. 411, p. 235-250, https://doi.org/10.1144/SP411.2.

Zahirovic, S., Flament, N., Müller, D., Seton, M., and Gurnis, M., 2016, Large fluctuations of shallow seas in low-lying Southeast Asia driven by mantle flow: Geochemistry Geophysics Geosystems, v. 17, p. 3589-3607, https:// doi.org/10.1002/2016GC006434. 